\title{
Are the Lake Baikal diatoms endemic?
}

\author{
S.I. Genkal ${ }^{1, *} \&$ N.A. Bondarenko ${ }^{2}$ \\ ${ }^{1}$ I.D. Papanin Institute of Inland Water Biology, Russian Academy of Sciences, 152742, Yaroslavl' province, Nekouzskiy \\ Region, Borok, Russia \\ ${ }^{2}$ Limnological Institute of Siberian Branch of Russian Academy of Sciences, 664033, Irkutsk, Ulan-Batorskaya str., \\ 3, Russia \\ (*Author for correspondence: E-mail: genkal@ibiw.yaroslavl.ru)
}

Key words: Lake Baikal, mountain and alpine lakes, Bacillariophyta, plankton, endemic, relict

\begin{abstract}
An electron-microscopy study of Aulacoseira baicalensis, A. islandica (A. skvortzowii), Cyclotella baicalensis, C. minuta, and Stephanodiscus meyerii in phytoplankton samples from some mountain lakes of Zabaikalye (an area north and east of Lake Baikal) shows that these algae possess morphological similarities with the algae inhabiting Lake Baikal, including some elements of their ultra-structure. We hypothesise that they were more widespread in the past and persist today in mountain lakes along the Baikal rift zone owing to certain features of their biology. We conclude that these baikalian diatom algae, previously regarded as endemic, should be re-assigned to relict status.
\end{abstract}

\section{Introduction}

In Lake Baikal, about $10 \%$ of planktonic algae have been found to be endemic (Kozhov, 1962, 1972). These are mostly diatoms, mainly Aulacoseira baicalensis (K. Meyer) Simonsen, Cyclotella baicalensis Skvortzow, C. minuta (Skvortzow) Antipova, and Stephanodiscus meyerii Popovskaya et Genkal. The problem of endemism among dominant algae in Lake Baikal plankton has long been discussed in the literature.

One of them, A. baicalensis, was considered to be a baikalian endemic, but after it was found as a fossil in sediments of Lake Medvezhie (Moscow Province) (Wertebnaja, 1928, 1929), Meyer (1922) proposed it was of relict status. Subsequent findings of living $A$. baicalensis in other water bodies were regarded as methodical errors. Skabichevsky (1960) proposed that the finding of A. baicalensis in Lake Dalai Nor in Manchzhuria (Skvortzow, 1937) indicated that the status of $A$. baicalensis as a relict endemic species, formerly widely spread, should be reviewed. Recently, valves of an alga very similar to $A$. baicalensis were found in deep layers of bottom sediments in Lake Washington (Abella, 1988) and may be a variety of $A$. baicalensis. Other authors now suggest a relatively young age of the present endemic species in Lake Baikal plankton, either that $A$. baicalensis originated in the lake 122 thousand years (Khursevich et al., 2001), or 107 thousand years ago (Grachev et al., 1998).

Spore forming Aulacoseira islandica from Lake Baikal was described as a new species $A$. skvortzowii Edlund, Stoermer et Taylor (Edlund et al., 1996) not found in other water bodies. However, spore-forming $A$. islandica was observed in Lake Khanka, Primorskiy Province, Russia (Skvortzow, 1929; Genkal \& Schure, 2000). The taxonomic position of this alga seems to require more study (Popovskaya et al., 2002).

S. meyerii was earlier referred to as Melosira binderana, and presently has been shifted to the genus Stephanodiscus. Differing from the typical variety, it was described as $S$. binderanus var. baicalensis Popovskaya et Genkal (Genkal \& Popovskaya, 1990), but later was given species rank as S. meyerii (Popovskaya et al., 2002). 
Findings have been reported (Rozhkova et al., 2000) of dinoflagellates of the genus Gymnodinium considered earlier as Lake Baikal endemic species, in the plankton of large mountain and alpine lakes of Zabaikalye (located in the River Lena basin). Other endemic species, namely diatoms from the genera Cyclotella and Melosira, have been found in the Pliocene flora of the Tunkinskaya depression adjacent to Lake Baikal (Cheremisinova, 1966, 1968, 1973), in Neogene deposits from the Tunkinskaya depression and Zabaikalye (Popova et al., 1989; Chernyaeva et al., 2000; Chernyaeva \& Moiseeva, 2003; and others), as well as in present plankton of Lake Khubsugul in Mongolia (Kozhova et al., 1977; Genkal et al., in press). Last, electron-microscopy studies of species composition of planktonic diatoms from the lakes of Zabaikalye, were reported by Genkal \& Bondarenko (2001, 2004).

This paper focuses on morphological features of algal forms similar to the Lake Baikal endemic species, from the Zabaikalye lakes using electron microscopy.

\section{Sites studied}

The lakes are located on the Sayano-Baikal highland east and north-east of Lake Baikal, stretching to the Kodar and Udokan ranges (Fig. 1). The Sayano-Baikal highland is an area of neotectonic activity and sharp orographic contrasts, with manifestations of volcanism and wide occurrence of glacial morpho-structures. It includes the Baikal rift zone as a whole morpho-structural complex (Logachev et al., 1974). The formation of the present relief was greatly affected by the Pleistocene glaciations, and seismic processes in Pleistocene and Holocene (Vdovin, 1976). Bazarov (1986) thought that the key moments in changes of palaeoclimate in the region have been cooling and Quaternary glaciations. The origin of the studied lakes is associated with glacial modifications of relief and melting of glaciers (Geologiya I seismichnost' zony BAM, 1983; Enikeev, 1998). Deposits of the second half of the Late Pleistocene are mainly glacial and aqua-glacial. Some of the lake depressions, for instance Oron and Tokko, have tectonic origins. Lake basins situated in river valleys lie along the tectonic break.

The lakes we studied are of ultra-oligotrophic type having relatively low temperatures and high oxygen content. They are covered with ice for 8-9 months a year. Destruction of ice-cover occurs most frequently during the first half of June, and the ice forms again in October. Water temperature rises until mid August, after that steadily decreases. All the lakes are flow-through. Soli, Tokko, Kamkanda give rise to rivers. Ogiendo,

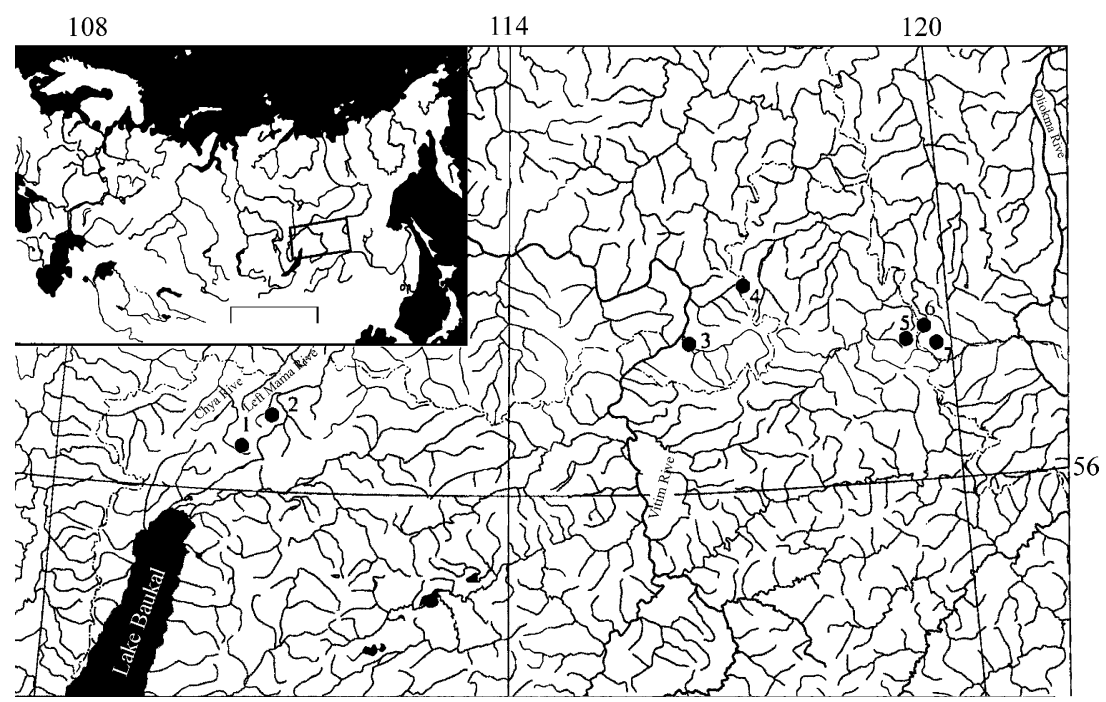

Figure 1. Scheme of the lake location. 1 - Ogiendo lakes; 2 - Lake Soli; 3 - Lake Oron; 4 - Amalyk lakes; 5 - Kiryalta lakes; 6 - Lake Tokko; 7 - Lake Kamkanda. 
Table 1. Composition of the Baikal endemic species in the studied lakes

\begin{tabular}{|c|c|c|c|c|c|c|c|}
\hline & Ogiendo & Soli & Amalyk & Oron & Kamkanda & Tokko & Kiryalta \\
\hline A. baicalensis & + & + & + & & + & + & + \\
\hline A. islandica (vegetative cells) & + & + & + & & + & & + \\
\hline A. islandica (spores) & + & + & & & + & & \\
\hline C. baicalensis & + & & & & & + & \\
\hline C. minuta & + & & + & & & + & \\
\hline S. meyerii & + & + & & + & + & & \\
\hline
\end{tabular}

Kiryalta, Amalyk are chains of lakes connected by surface water-flows, with elevation differences reaching 150-180 m. Except Lake Oron (19 km long and $184 \mathrm{~m}$ maximum depth), all the lakes are small, from 0.6 to $4.6 \mathrm{~km}$ long and $11-52 \mathrm{~m}$ deep.

\section{Methods}

Phytoplankton was sampled during the open water period over 1997-2001 in all the lakes. In Lake Ogiendo samples were also taken during the iced period. Net and water-sampler were used. The samples fixed with Utermohl solution were concentrated using sedimentation. Samples were first examined in a $0.1 \mathrm{ml}$ chamber by "Pereval" microscope at magnifications $\times 720$ and $\times 1200$. The cells were separated from organic material by wet digestion (Balonov, 1975). Algae preparations were examined by electron microscope SEM "JSM-25 S".

\section{Results}

All the known baikalian planktonic endemic species of Bacillariophyta were found in 7 of the 30 lakes sampled (Table 1). As the taxonomic status of baikalian spore-forming algae required additional study, we bracketed all samples of this species as $A$. islandica. According to the most recent opinion of Popovskaya et al. (2002), previously described intra-species taxa in A. baicalensis, $C$. baicalensis, and C. minuta may now be considered as synonyms. A complex of endemic species was recorded in Ogiendo lakes (Table 1). In Lake Soli, four endemic species were recorded, three in Amalyk, Kamkanda, and Tokko, two in Kiryalta, and only one in Oron (Table 1).
S. meyerii and C. minuta abounded mainly in the Ogiendo lakes (Table 2). C. baicalensis was represented only by solitary valves in Tokko and Ogiendo, which probably reflected scanty phytoplankton at the sampling time. In Lake Baikal, this alga thrives in spring, while $C$. minuta, which reaches its development maximum in autumn, is encountered all the year round (Popovskaya et al., 2002). The most widespread species in the lakes, A. baicalensis (Table 1), showed highest abundance in Lake Soli (Table 2). A. islandica was found in five lakes: Ogiendo, Soli, Kamkanda, Kiryalta, and Amalyk, and its spores in the first three of these (Table 1). The greatest number of spores was recorded in Kamkanda (Table 2).

The morphological characters, including some elements of ultra-structure, viz. shape of spines, structure and location of fultoportulae and rimoportulae, areols and alveols in the endemic species (Figs. 2 and 3) agree completely with taxonomic diagnoses (Genkal \& Popovskaya, 1990, 1991; Likhoshway et al., 1992; Babanazarova et al., 1996; Edlund et al., 1996; Popovskaya et al., 2002). S. meyerii is the exception, having fewer numbers of striae per 10 microns and spine appendages (Table 2). This deviation may be related with geographic variability. As regards spine appendages, the diagnosis covers their usual number, though the baikalian forms of this species also have valves with spines possessing 3 or 4 appendages (Popovskaya et al., 2002; Table 11, 1-3).

\section{Discussion}

Occurrences of baikalian organisms in other lakes, distant from Lake Baikal, have been discussed in the literature for a long time. Several suggestions 


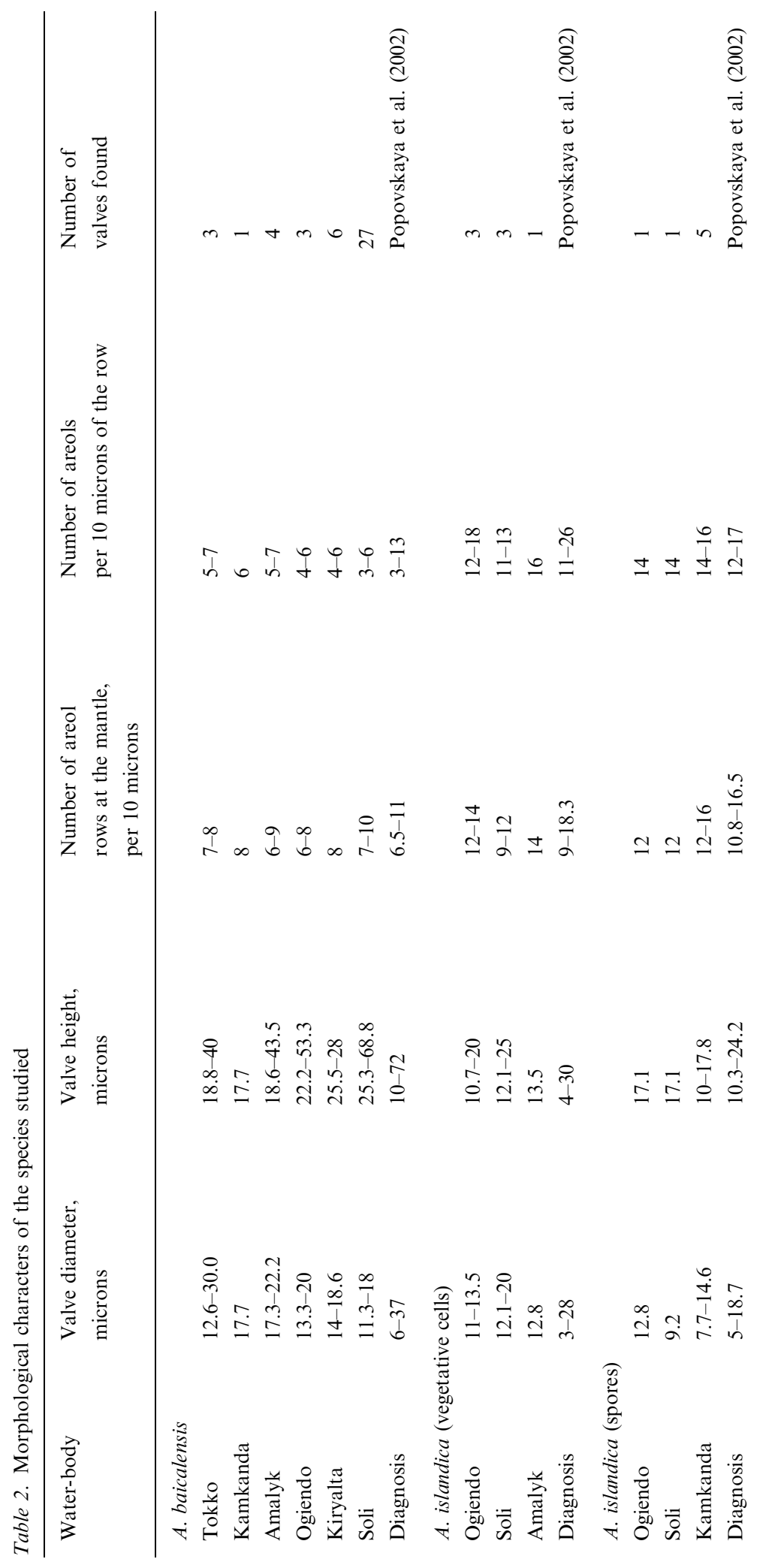



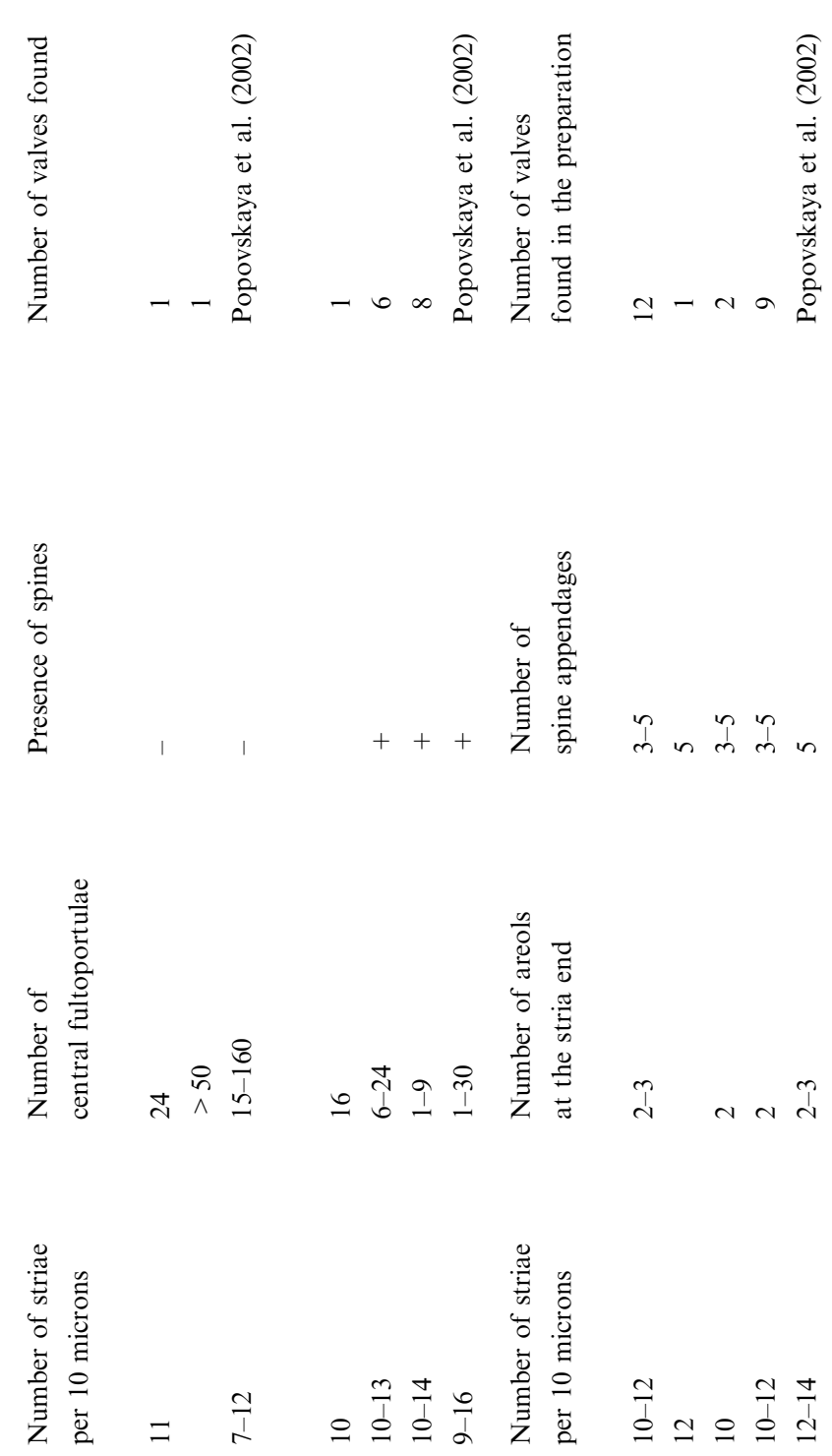

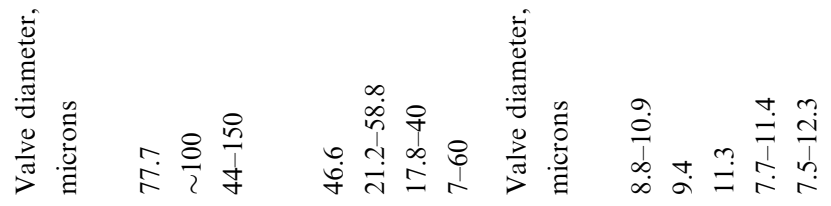

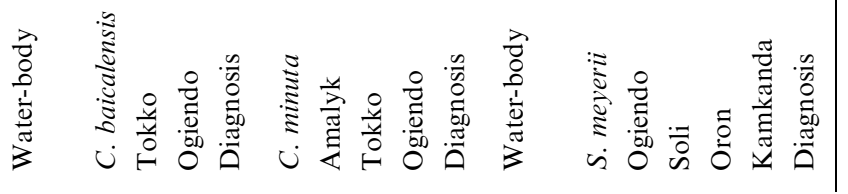



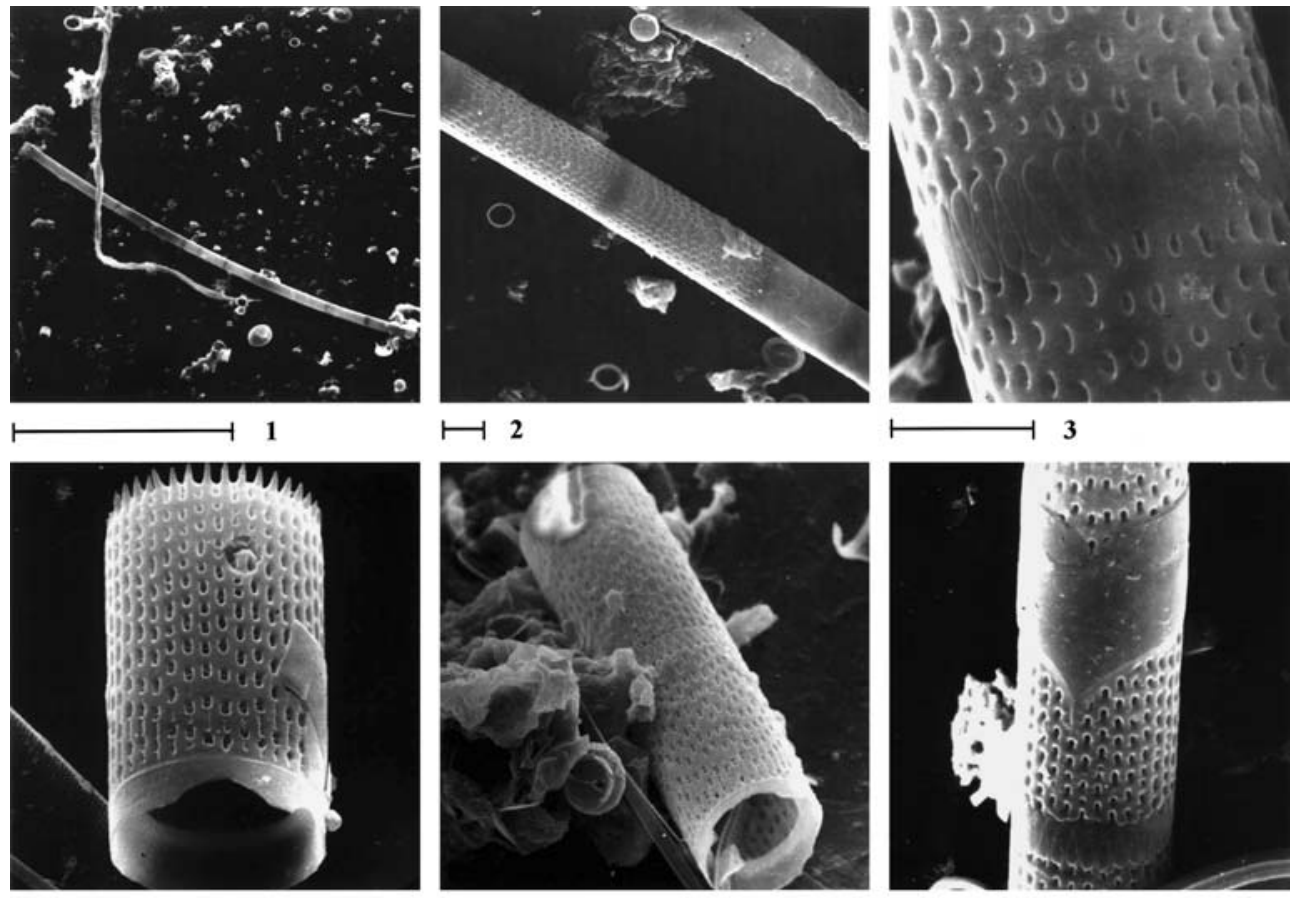

$\longmapsto 2$
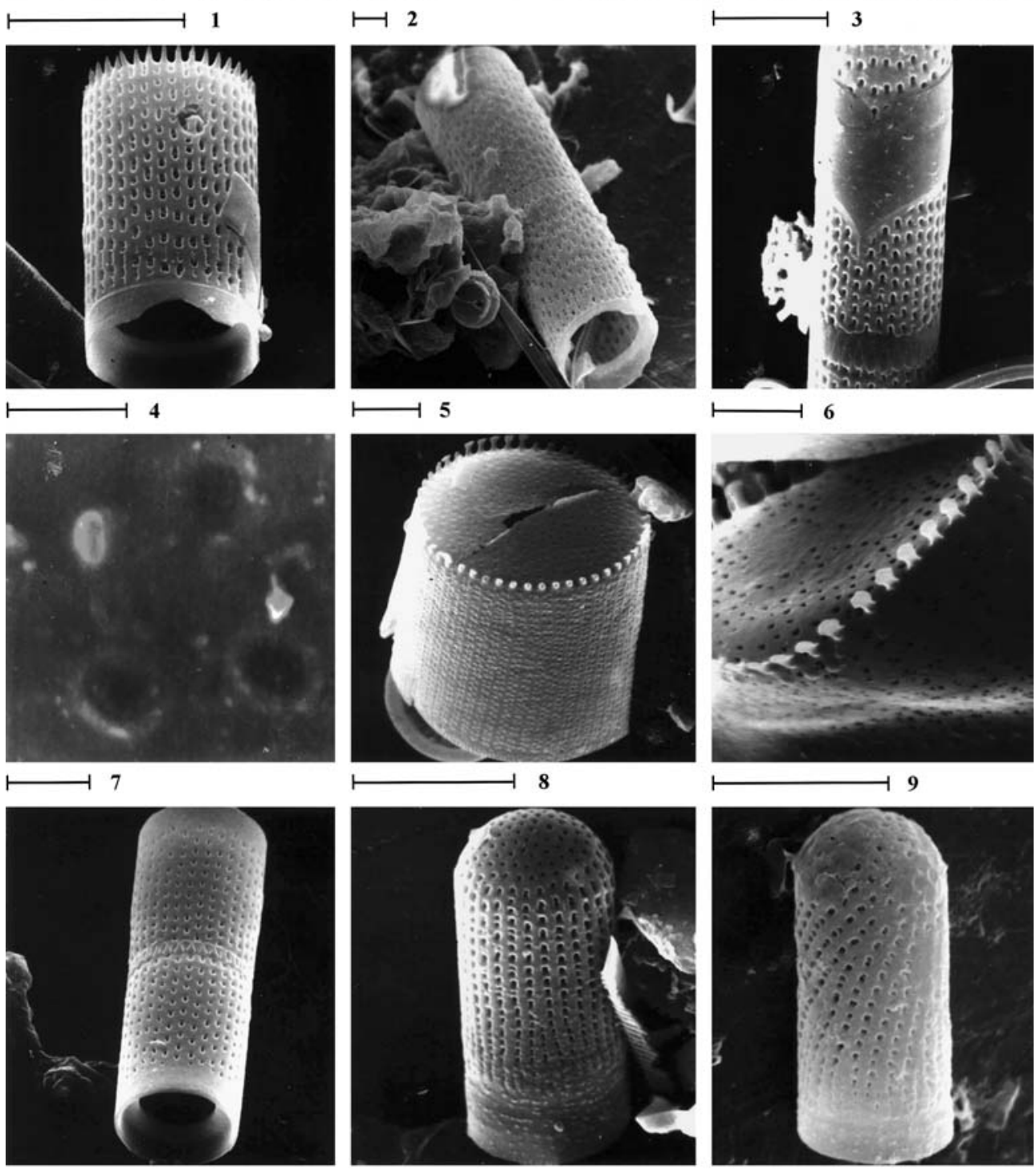

10

11

112

Figure 2. Electronic microphotographs of valves (SEM): 1-7 - A. baicalensis; 8-12 - A. islandica. 1 - colony; 2 - valves of this colony; 3 - spines in this colony; 4, 5, 8-10 - valves; 6 - girdle band; 7 - rimoportula of the inner surface; 11,12 - spores. Scale bars: $1-50 \mu \mathrm{m}$; $2,4-6,8,10-12-10 \mu \mathrm{m} ; 3,9-5 \mu \mathrm{m} ; 7-1 \mu \mathrm{m}$. 


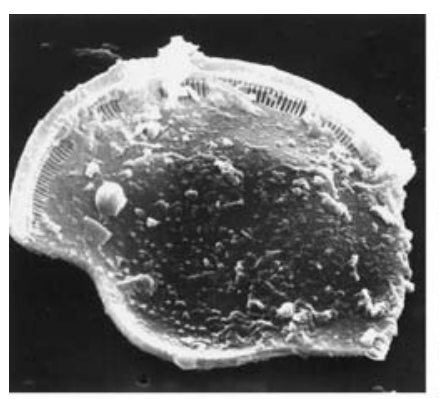

$\longmapsto 1$

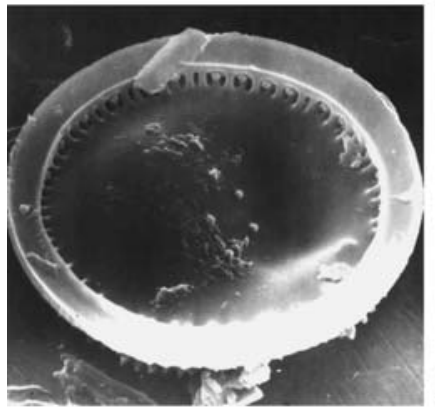

$\longmapsto 4$
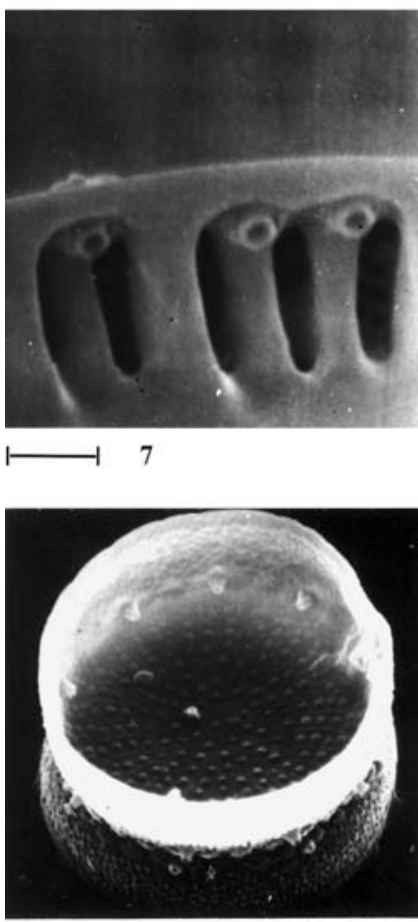

10

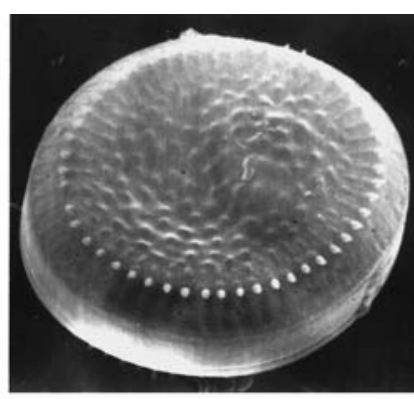

2
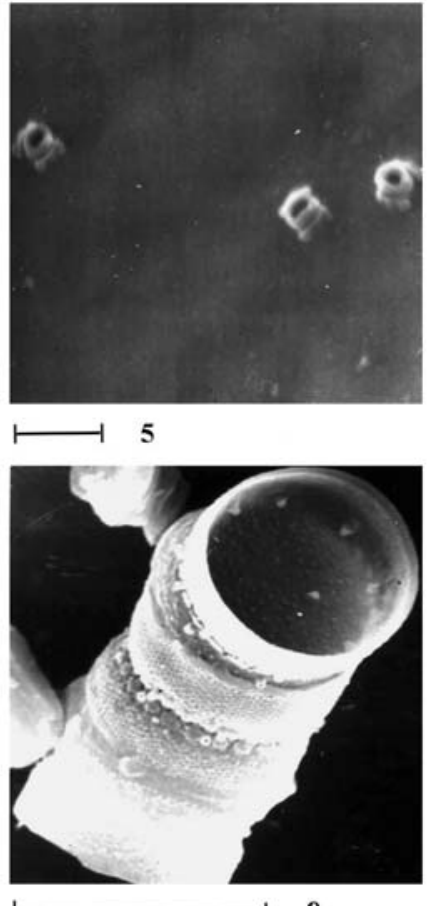

8

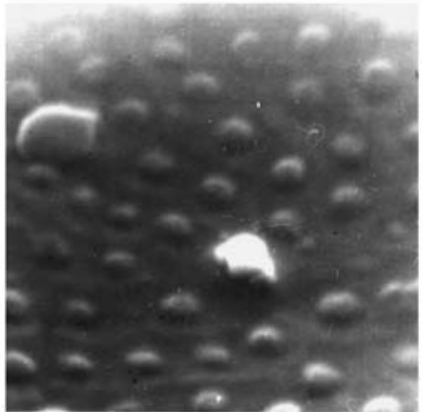

11

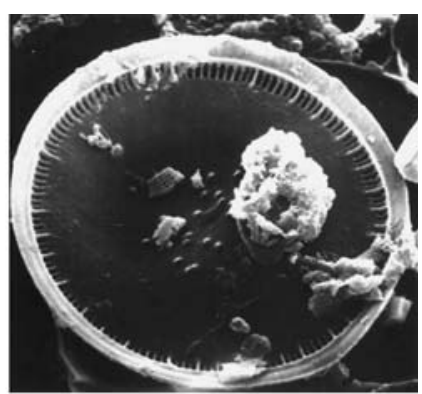

$\longmapsto 3$
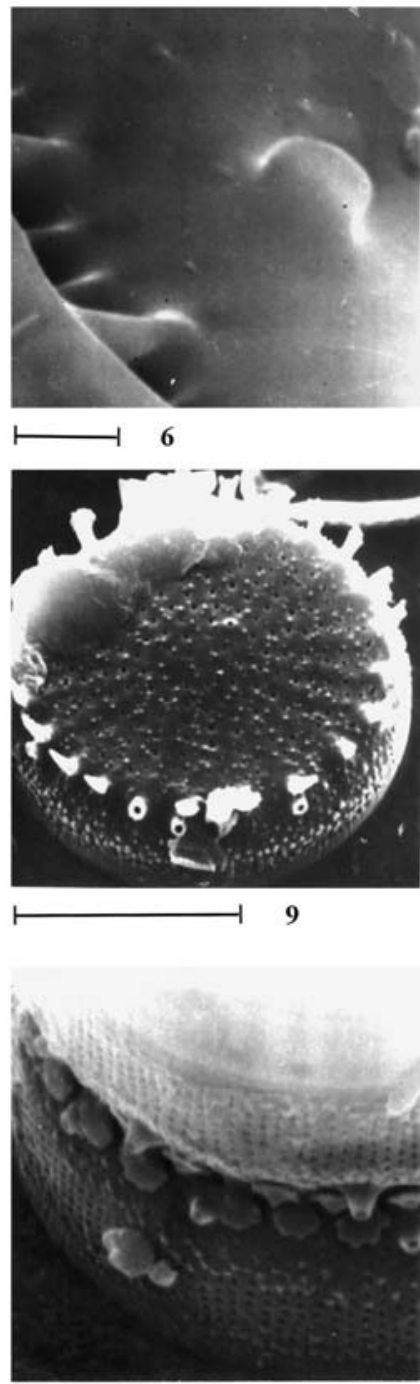

12

Figure 3. Electronic microphotographs of valves (SEM): 1-C. baicalensis; 2-7-C. minuta; 8-12-S. meyerii. 1, 3, 4, 7 -valves from the inner surface; 2,9 - valves from the outer surface; 5 - fultoportulae on a valve from the inner surface; 6 - rimoportula from the inner surface; 7 - marginal fultoportulae on a valve from the inner surface; 8 - colony; 11 - fultoportula on a valve from the inner surface; 12 - spines and marginal fultoportulae from the outer surface. Scale bars: $1-4-10 \mu \mathrm{m} ; 5-7,11,12-1 \mu \mathrm{m} ; 9,10-5 \mu \mathrm{m}$. 
have been made. Tomilov (1954) thought the Zabaikalye lakes, located in basins of two River Lena tributaries, Vitim and Olyokma, have a similar origin; it is possible to consider them as an inheritance of the last phase of the Glacial period. According to this view, the presence of some baikalian endemic and relict species in certain of the lakes indicates they existed as water bodies before the Glacial period. During the interglacial or some later time before the present, they were connected with other large basins. In the past, there was a chain of gigantic lakes in Baikal-type depressions populated by elements, which had invaded from Lake Baikal. Such dispersal of baikalian elements took place at the end of Neogene and early Quaternary along the river system directed towards the Lena through these ancient lakes (Kozhov \& Tomilov, 1949). Kozhov $(1950,1962)$ also thought that the Zabaikalye lakes represented depressions of the Baikal system, which were an integral system in the past, or were closely connected with each other through short rivers. He regarded them as successors of an ancient Baikal multi-lake country.

According to Karasiov (1987), geological and biological data do not support the hypothesis of Kozhov (1950, 1962). Moreover, Baikal transgression into Zabaikalye and the resulting formation of a vast "Zabaikalye multi-lake country" was refuted by Florensov (1960), who showed there had not been a significant rise of Lake Baikal level and thus no transgression. So, a significant fraction of the so-called "Baikal hydro-fauna" must have been common to the rift (Karasiov, 1987). In later time, this fauna persisted to a greater extent in Lake Baikal (ecologically more diverse) and to a lesser extent in the relict margin lakes of the rift zone. In Neogene, before a period of rapid rise of the ranges in the vicinity of Lake Baikal on the watershed of the Olyokma-Vitim highland, there was an ancient lake district with water discharge towards both palaeo-Baikal through the palaeoBarguzin and palaeo-basins of Vitim and Oyokma. The Neogene and Early Quaternary watershed lakes were deeper than $200 \mathrm{~m}$ and had diverse autochthonous floras and faunas.

In Karasiov's (loc. cit.) view, there are no grounds for believing that all so-called "Baikal" species living outside Lake Baikal, evolved in the lake and spread from it. These forms and their predecessors inhabited the Baikal rift as early as the Tertiary period before the formation of Lake Baikal itself. In the Quaternary, the remains of the hydro-fauna of the mountain belt became isolated in separate refuges, which presumably maintained environmental conditions similar to former epochs. These relict bodies preserved some Tertiary hydrobionts till the present.

From Miocene deposits located in the Tunkinskaya depression (south-west of Lake Baikal along the Baikal rift zone), Likhoshway et al. (1997) used electron microscopy to describe representatives of the genus Aulacoseira. Some of them show similarity with $A$. baicalensis in their areol structure, location frequency and spine shape. These forms were thought to be ancestral to A. baicalensis. In the Pliocene deposits of Lake Baikal, Aulacoseira valves similar to those of A. baicalensis were also found (Likhoshway, 2004). In Pleistocene deposits of the Upper Angara depression (north-east part of the Baikal rift zone), valves of the Lake Baikal endemics $A$. baicalensis, C. baicalensis, and C. minuta were found by Kulchitsky et al. (1993) who explain their presence by repeated transgressions of Lake Baikal into the depression.

Investigations on Vitim highland revealed deposits of large deep lakes, which had passed through repeated phases of deposition (Chernyaeva et al., 2000). Rich diatom complexes including A. baicalensis were found in these deposits. It was suggested this species developed in lakes in the Zabaikalye area and lakes formerly occupying present Baikal. Later it disappeared over most of its distribution area, persisting only in Lake Baikal.

Ancient lake deposits formed prior to glacial periods have also been found in the trough of the Baikal rift at the south-west end of the Muyakanskaya depression, between the Upper Angara River and Muysko-Kuandinskaya depression. Analysis has shown they contain valves of extant diatoms, baikalian endemic A. baicalensis, C. baicalensis Skv., C. aff. minuta Antip., as well as $A$. aff. islandica ssp. helvetica (O. Müll.) Sim.; and spores of Aulacoseira (Kulchintsky et al., 1993). It was suggested these Baikal endemic diatoms were earlier distributed in lakes close to it in the rift trough, and later penetrated into Lake Baikal. Favourable environmental conditions have preserved these species in Lake Baikal. 
Deposits of the Charskaya depression (Zabaikalye, north-east of the Baikal rift zone) have revealed diatom complexes of ancient lakes, which now have disappeared (Chernyaeva \& Moiseeva, 2003). In the Upper Miocene-Early Pliocene complexes, algae occur together with other representatives of the genus Aulacoseira identified as $A$. aff. baicalensis. From this and other findings it was proposed that the spread of A. baicalensis into East Siberia lakes started not from Lake Baikal but rather from the Zabaikalye lakes, which existed during the Neogene on the Vitim highland where the species occurred in sediments dated around the Mid Miocene. These authors believe it is incorrect to refer to A. baicalensis as a Baikal endemic.

Our study supports the latter conclusion and agrees with Skabichevsky (1960). In the past, A. baicalensis or (and) its close relatives appear to have occupied a vast area, including North America, Europe, and the Far East. At present this alga, as the other planktonic diatoms cited here, inhabits, beside Baikal, the Zabaikalye lakes in the north of the Baikal rift zone from the North Baikal highlands to the Kodar and Udokan ranges. Three representatives occur also in the south-west of the rift zone in Lake Khubsugul (Genkal et al., in press). So, A. baicalensis and the spore forming $A$. islandica are quite common in the region.

How have these algae persisted through many climatic and geological changes? In our view, certain biological peculiarities may help provide an explanation. First, they are meroplanktonic organisms: after growth in the water column they produce a resting stage that falls to the bottom where they can remain a long time. Furthermore they are ice organisms; their life cycle begins in the interstitial water in ice. In fact, the most productive bloom, in spring, takes place there (This was recently shown for the baikalian Aulacoseira species - Bondarenko, 2002; Obolkina et al., 2000 - and for $A$. islandica, living in the river Amur Yuriev \& Lebedev, 1988). The phenomenon suggests an underlying cause for their survival in the East Siberia lakes. Concerning to the other three representatives, $S$. meyerii, $C$. baicalensis, and C. minuta, their propagation in interstitial ice water has not yet been recorded, but it is well known that being meroplanktonic they can persist frozen into the ice until spring. Tolerance of ice conditions may have played a main role in the survival of these algae during Pliocene-Pleistocene glaciations.

\section{Conclusion}

We conclude that all these baikalian planktonic diatom algae, previously regarded as endemic, should be reassigned to relict status. High mountain lakes of Pribaikalye and Zabaikalye presently serve as refuges for species widespread during past geological epochs. Researchers of the higher terrestrial vegetation have come to a similar conclusion: i.e. that prolonged influence of low temperatures, orographic and ecological isolation of separate inter-mountain lowlands and highlands, which originated during the NeogenePleistocene tectogenesis, facilitated formation of a great number of new endemics and the preservation of relicts in the high mountain flora (Predbaikalye and Zabaikalye, 1965; Peshkova, 2001).

\section{Acknowledgements}

The authors thank Prof. V.G. Sideleva and Dr. N.V. Kulagina for helpful discussions during preparation of the manuscript. Also, we are grateful Prof. G. Coulter for his kind help in refining an English version of the manuscript.

\section{References}

Abella, S. E. B., 1988. The effect of the Mt. Mazama ashfall on the planktonic diatom community of Lake Washington. Limnology and Oceanography 33: 1376-1385.

Babanazarova, O. V., Ye. V. Likhoshway \& D. Yu. Sherbakov, 1996. On the morphological variability of Aulacoseira baicalensis and Aulacoseira islandica (Bacillariophyta) of Lake Baikal, Russia. Phycologia 35: 113-123.

Balonov, I. M., 1975. Podgotovka diatomovykh i zolotistykh vodorosley $\mathrm{k}$ elektronnoy microskopii. [Preparation of diatom and golden algae for electron microscopy]. In Mordukhai-Boltovskoi, F. D. (ed.), Metodiki izucheniya Biogeotsenozov Vnutrennikh Vodoyemov [Methods in Studying Biocoenoses of Inland Waters]. Nauka, Moscow, 87-90 (In Russian). 
Bazarov, D. D. B., 1986. Cenozoic in Pribaikalye and West Zabaikalye [Kaynozoy v Pribaikal'ye i zapadnom Zabaikal'ye]. Nauka, Novosibirsk (in Russian).

Bondarenko N. A., 2002. Osobennosti biologii vodorosley roda Aulacoseira na primere ego baikal'skikh predstaviteley [Peculiarities of biology in algae of Baikal representatives of the genus Aulacoseira]. In VIII school of diatomologists of Russia and SNG countries "Morfologiya, ekologiya i biogeografiya diatomovykh vodorosley" [Morphology, ecology and biogeography of diatom algae], Borok, 16-19 September 2002. Abstracts. Borok, 10-11 (in Russian).

Cheremisinova, E. A., 1966. K voprosu o vozraste oz. Baikal (rezul'taty diatomovogo analiza otlozheniy Tunkinskoy kotloviny [The problem of Lake Baikal age (results of diatom analysis of the Tunkinskaya depression deposits)]. Doklady Akademii Nauk SSSR [Reports of Academy of Sciences of USSR] 171: 948-951 (in Russian).

Cheremisinova, E. A., 1968. Novye Dannye o Diatomeyakh Neogenovykh Otlozheniy Pribaikal'ya [New Data about Diatoms of the Neogene Deposits of Pribaikalye]. In Iskopaemye Diatomovye Vodorosli SSSR [Fossil Diatom Algae of USSR]. Nauka, Moscow, 71-74 (in Russian).

Cheremisinova, E. A., 1973. Diatomovaya Flora Neogenovykh Otlozheniy Pribaikal'ya [Diatom Flora of Neogene Deposits of Pribaikalye]. Nauka, Sibirian department, Novosibirsk (in Russian).

Chernyaeva, G. P., S. V. Rasskazov, I. S. Brandt \& S. B. Bandt, 2000. Palaeolimnology of Miocene lakes of the Vitim highland (Zabaikalye). In The third Vereshchagin Baikal conference. Abstracts. Irkutsk, 22-27 August 2000. Irkutsk: 268.

Chernyaeva, G. P. \& A. I. Moiseeva, 2003. Diatomei pozdnekaynozoyskikh otlozheniy Charskoy vpadiny (Zabaikal'ye) [Diatoms of the Late Cenozoic deposits of the Charsk depression (Zabaikalye)]. Geografiya i prirodnye resursy [Geography and natural recourses] 3: 84-91 (in Russian).

Edlund, M. B., E. F. Stoermer \& C. M. Taylor, 1996. Aulacoseira skvortzowii sp. nov. (Bacillariophyta), poorly understood diatom from Lake Baikal, Russia. Phycology 32: 165-175.

Enikeev, F. I., 1998. Istoriya razvitiya vostochnoy chasti Baikal'skoy riftovoy zony [History of development of the eastern part of the Baikal rift zone]. In Lokot', L.I. (ed.), Vidovaya Struktura Gidrobiotsenozov ozyer i rek Gornykh Territoriy [Species Structure of Hydrobiocoenoses of Mountain Lakes and Rivers]. Russian Academy of Sciences Publishers, Novosibirsk, 5-20 (in Russian).

Florensov, N. A., 1960. Mezozoiskie i Kaynozoyskie Vpadiny Pribaikal'ya [Mesozoic and Cenozoic depressions in Pribaikalye]. Publishers of Academy of Sciences of USSR, Moscow-Leningrad (in Russian).

Genkal, S. I. \& N. A. Bondarenko, 2001. Materialy k flore vodorosley (Centrophyceae, Bacillariophyta) nekotorykh ozer Pribaikal'ya i Zabaikal'ya [Floral study of algae (Centrophyceae, Bacillariophyta) in some lakes of Pribaikalie and Zabaikalie]. Biologiya vnutrennikh vod [Biology of Inland Waters] 1: 3-10 (in Russian).

Genkal, S. I. \& N. A. Bondarenko, 2004. Elektronnomicroskopicheskoe izuchenie Bacillariophyta planktona gornykh ozer basseyna r. Leny [Electron microscopic studies of Bacillariophyta in the plankton of mountain lakes of the Lena basin]. I. Centrophyceae Botanicheskiy zhurnal [Botanical. Journal] 89: 1588-1596 (in Russian).

Genkal, S. I. \& G. I. Popovskaya, 1990. Novy predstavitel' roda Stephanodiscus Ehr. (S. binderanus (Kütz.) Kreig. var. baicalensis Popovsk. et Genkal var. nov.) [New representative of the genus Stephanodiscus Ehr. (S. binderanus (Kütz.) Kreig. var. baicalensis Popovsk. et Genkal var. nov.)]. Biologiya vnutrennikh vod [Biology of Inland Waters] 85: 27-31 (in Russian).

Genkal, S. I. \& G. I. Popovskaya, 1991. K morfologii i ekologii Aulacosira baicalensis (Bacillariophyta) [Morphology and ecology of Aulacosira baicalensis (Bacillariophyta)]. Botanicheskiy zhurnal [Botanical. Journal] 76: 292-293 (in Russian).

Genkal, S. I. \& L. A. Schure, 2000. Novye dannye k flore Bacillariophyta $\mathrm{v}$ ozere Khanka [New data on the flora of Bacillariophyta in Lake Khanka (Primorskiy Province, Russia)]. Al'gologiya [Algology] 10: 278-281 (in Russian).

Genkal, S. I., G. I. Popovskaya, O. I. Belykh \& A. D. Firsova, (in press). Novye $\mathrm{i}$ interesnye diatomovye vodorosli $\mathrm{v}$ planktone ozera Khubsugul [New interesting diatom algae in Lake Khubsugul plankton]. I. Centrophyceae (in Russian).

Geologiya i seismichnost' zony BAM, 1983. [Geology and Seismic Characters of the BAM zone]. In Logachev, N.A. (ed), Cenozoic Deposits and Geomorphology [Kaynozoyskie Otlozheniya i Geomorfologiya]. Nauka, Novosibirsk (in Russian).

Grachev, M. A., S. S. Vorobyova \& Ye. V. Likhoshway et al. 1998. A high-resolution diatom record of the palaeoclimates of East Siberia for the last $2.5 \mathrm{My}$ from Lake Baikal. Quaternary Science Reviews 17: 1101-1106.

Karasiov, G. L., 1987. Ryby Zabaikal'ya [Fishes of Zabaikalye]. Nauka, Siberian Branch, Novosibirsk.

Khursevich, G. K., E. B. Karabanov, A. A. Prokopenko, D. V. Williams, M. I. Kuzmin, S. A. Fedenya, A. N. Gvozdkov \& E. B. Kerber, 2001. Detal'naya diatomovaya biostratigrafiya osadkov ozera Baikal v epokhu Bryunes i klimaticheskie faktory vidoobrazovaniya [Detailed diatom biological stratification of Lake Baikal deposits in the Brunhes and climatic factors of species formation]. Geologiya i geofizika [Geology and geophysics] 42: 108-129 (in Russian).

Kozhov, M. M., 1950. Presnye vody Vostochnoy Sibiri [Freshwaters of East Siberia ]. Regional Irkutsk State Publishers, Irkutsk (in Russian)

Kozhov, M. M., 1962. Biologiya Ozera Baikal [Biology of Lake Baikal]. Academy of Sciences of USSR Publishers, Moscow (in Russian).

Kozhov, M. M., 1972. Ocherki po Baikalovedeniyu [Essays on Lake Baikal studies]. East Siberian Publishers, Irkutsk (in Russian).

Kozhov, M. M. \& A. E. Tomilov, 1949. O novykh nakhodkakh elementov baikal'skoy fauny vne Baikala [On new findings of the elements of the Baikal fauna outside Baikal]. Trudy Vsesoyuznogo gidrobiologicheskogo obshchestva [Proceedings of USSR Hydrobiological Society] 1: 224-227 (in Russian).

Kozhova, O. V., G. F. Zagorenko \& E. N. Ladeishchikova, 1977. Osobennosti fitoplanktona oz. Khubsugul v godovom 
i sezonnom aspectakh [Peculiarities of Lake Khubsugul phytoplankton in the annual and seasonal aspects]. Gidrobiologicheskiy zhurnal [Hydrobiological Journal] 13: 77-82 (In Russian).

Kulchitsky, A. A., G. P. Chernyaeva, V. A. Misharina, I. A. Kalashnikova \& L. V. Bardunov, 1993. Osobennosti formirovaniya pleistotsenovykh otlozheniy vpadin severo-vostochnogo flanga baikal'skoy riftovoy zony [Peculiarities of formation of the Pleistocene deposits in depression of the North-East flank of the Baikal rift zone]. In Sizykh, A. I. (ed.), Geologiya i Poleznye Iskopaemye Vostochnoy Sibiri [Geology and Mineral Resources of East Siberia]. Irkutsk University Publishers, Irkutsk, 63-66 (in Russian).

Likhoshway Ye. V., A. O. Yakushin, A. P. Pizyr \& N. A. Bondarenko, 1992. Fine structure of the velum and girdle bands in Aulacoseira baicalensis. Diatom Research 7: 87-94.

Likhoshway, Ye.V., 2004. Evolyutsiya diatomovykh vodorosley roda Aulacoseira Thwaites v ozere Baikal]. Evolution of diatom algae of the genus Aulacoseira Thwaites in Lake Baikal]. Doctoral Thesis. Novosibirsk (in Russian).

Likhoshway, Ye. V., G. V. Pomazkina \& T. A. Nikiteeva, 1997. Tsentrichnye diatomovye iz miotsenovykh otlozheniy baikal'skoy riftovoy zony [Centric diatoms from the Miocene deposits of the Baikal Rift Zone (Tunkinskaya Depression)]. Geologiya i Geofizika [Geology and Geophysics] 38: 14451452 (in Russian).

Logachev, N. A., I. V. Antoshchenko \& D. B. Bazarov et al. 1974. Nagor'ya Pribaikal'ya i Zabaikal'ya [Highlands of Pribaikalye and Zabaikalye]. Nauka, Moscow (in Russian).

Meyer, K. I., 1922. Materialy po flore vodorosley oz. Baikal [Data on the algal flora of Lake Baikal]. Zhurnal Moskovskogo otdeleniya Russkogo botanicheskogo obschestva [Journal of Moscow Department of Russian Botanical Society] 1: 1-27 (in Russian).

Moiseeva, A. I., I. A. Kuptsova, E. G. Lupikina \& E. A. Cheremisinova, 1974. Pliotsenovye diatomovye [The Pliocene diatoms]. In Gleser, S. I., A. P. Zhuze \& I. V. Makarova et al. (eds), Diatomovye vodorosli SSSR (iskopaemye i sovremennye [Diatom algae of USSR (fossil and present)]. Nauka, Leningrad 1: 204-224 (in Russian).

Obolkina L. A., N. A. Bondarenko, L. F. Doroshenko, L. A. Gorbunova \& O. A. Molozhavaya, 2000. O nakhodke kriofil'nogo soobshchestva $v$ ozere Baikal [On the finding of a cryophillic community in Lake Baikal]. Doklady Akademii Nauk [Reports of Russian Academy of Sciences]. 371: 815817 (in Russian).

Peshkova, G. A., 2001. Florogeneticheskiy Analiz Stepnoy Flory gor Yuzhnoy Sibiri [Florogenetic Analysis of the Steppe Flora of South Siberia Mountains]. Nauka, Novosibirsk (in Russian).

Popova, S. M., V. D. Mats \& G. P. Chernyaeva et al. 1989. Paleolimnologicheskiye Rekonstruktsii Baikal'skoy Riftovoy Zony [Palaeolimnological Reconstructions of Baikal Rift Zone]. Nauka, Novosibirsk (in Russian).
Popovskaya, G. I., S. I. Genkal \& Ye. V. Likhoshway, 2002. Diatomovye vodorosli planktona Ozera Baikal: Atlas-opredelitel [Diatom Algae of Lake Baikal Plankton: Key atlas]. Nauka, Novosibirsk (in Russian).

Predbaikal'ye i Zabaikal'ye [Predbaikalye and Zabaikalye], 1965. Nauka, Moscow. (In Russian).

Rozhkova, N. A., L. S. Kravtsova, N. A. Bondarenko, N. G. Sheveleva, T. Ya. Sitnikova, Z. V. Slugina, V. P. Samusenok, A. N. Matveev, I. B. Knizhin, B. A. Bogdanov \& S. S. Alexeev, 2000. Bioraznoobrazie vysokogornykh ozyer Severnogo Zabaikal'ya [Biodiversity of high mountain lakes of North Zabaikalye]. Trudy mezhdunarodnoy konferentsii "Ozyera kholodnykh regionov" [Proceedings of International conference "Lakes of cold regions"]. Part II. Hydrobiological problems. Yakutsk: 152-163 (in Russian).

Skabichevsky, A. P., 1960. Planktonnye Diatomovye Vodorosli Presnykh vod SSSR [Plankton Diatom Algae of USSR freshwaters]. Moscow University Publishers, Moscow (in Russian).

Skvortzow, B. W., 1937. Bottom Diatoms from the Olkhon gate of Lake Baikal, Siberia. The Philippine Journal of Science published by the Bureau of Science. Department of Agriculture and Commerce, Manila 3: 293-377.

Skvortzow, B. W., 1929. Materialy po izucheniyu vodorosley Primorskoy gubernii [Data on algae studies in the Primorskiy Province]. Diatom algae of Lake Khanka. Zapiski Yuzhno-Ussuriyskogo otdela Gosudarstvennogo russkogo geograficheskogo obschestva [Notes of the South-Ussuri Department of the Russian State Geographic Society. 3. Vladivostok (in Russian).

Tomilov, A. A., 1954. Materialy po gidrobiologii nekotorykh glubokovodnykh ozyer Olyekmo-Vitimskoy gornoy strany [Data on hydrobiology of some deep-water lakes of the Olyokma-Vitim mountain area]. In Deulya, T. T. (ed.), Trudy Irkutskogo gosudarstvennogo universiteta [Proceedings of Irkutsk State University]. XI. Biological series. Leningrad University Publishers, Leningrad, 5-86 (in Russian).

Vdovin, V. V., 1976. Osnovnye Etapy Razvitiya Rel'efa [Main Stages in Relief Development]. Nauka, Moscow (in Russian).

Wertebnaja, P. I., 1928. Reliktovaya flora v ozyernykh osadkakh Sredney Rossii [The relict flora of algae in Middle Russia lake deposits]. Dnevnik Vsesoyuznogo s'ezda botanikov v Leningrade v yanvare 1928]. Proceedings of the USSR Botanical conference in Leningrad in January 1928]. Leningrad: 124-133 (in Russian).

Wertebnaja, P. I., 1929. Uber eine relikte Algenflora in den Seenablagerungen Mittelrusslands. Archiv für Hydrobiologie 1: $124-133$

Yuriev, D. N. \& Yu. M. Lebedev, 1988. Razvitie ledovogo perifitona r. Amur v svyazi so svetovym faktorom [Development of ice periphytone in the Amur River in connection with light as a factor]. Botanicheskiy Zhurnal [Botanical Journal] 11: 1546-1551 (in Russian). 